\title{
Vancomycin pharmacokinetics during high-volume continuous venovenous hemofiltration in critically ill septic patients
}

\author{
Nadezda Petejovaa , Arnost Martineka, Jana Zahalkova ${ }^{b, c}$, Jana Duricova ${ }^{d}$, Hana Brozmannovad , Karel Urbaneke, \\ Milan Grundmann ${ }^{d}$, Jiri Plasek ${ }^{\text {a }}$ Ivana Kacirova ${ }^{d}$
}

\begin{abstract}
Aims. To assess the influence of continuous venovenous hemofiltration (CVVH) at a filtration rate of $45 \mathrm{~mL} / \mathrm{kg} / \mathrm{h}$ on vancomycin pharmacokinetics in critically ill septic patients with acute kidney injury (AKI).

Methods. Seventeen adult septic patients with acute kidney injury treated with CVVH and vancomycin were included. All patients received first dose of $1.0 \mathrm{~g}$ intravenously followed by $1.0 \mathrm{~g} / 12 \mathrm{~h}$ if not adjusted. In sixteen patients vancomycin was introduced on the day of the start of CRRT therapy. Blood samples and ultrafiltrates were obtained before and $0.5,1,6$ and $12 \mathrm{~h}$ after vancomycin administration.

Results. On the first day, the median total vancomycin clearance $\left(\mathrm{Cl}_{\text {tor }}\right)$ was $0.89 \mathrm{~mL} / \mathrm{min} / \mathrm{kg}$ (range 0.31 - 2.16). CRRT clearance accounted for around $50-60 \%$ of the total clearance of vancomycin found in a population with normal renal function $(0.97 \mathrm{~mL} / \mathrm{min} / \mathrm{kg})$. Vancomycin serum concentrations after the first dose were below the required target of $10 \mathrm{mg} / \mathrm{L}$ as early as $6 \mathrm{~h}$ in 10 patients, $\mathrm{AUC}_{0-24} / \mathrm{MIC} \geq 400$ ratio was achieved in 10 patients on the first day.

Conclusions. CVVH at a filtration rate of $45 \mathrm{~mL} / \mathrm{kg} / \mathrm{h}$ leads to high and rapid extracorporeal removal of vancomycin in critically ill patients. Due to the rapid change in patient clinical status it was impossible to predict a fixed dosage regimen. We recommend blood sampling as early as $6 \mathrm{~h}$ after first vancomycin dose with maintenance dose based on vancomycin serum level monitoring.
\end{abstract}

Key words: acute kidney injury, critically ill patients, renal replacement therapy, sepsis, drug monitoring, vancomycin

Received: April 16, 2012; Accepted with revision: September 18, 2012; Available online: November 6, 2012

http://dx.doi.org/10.5507/bp.2012.092

${ }^{a}$ Department of Internal Medicine, Faculty of Medicine, University of Ostrava and University Hospital Ostrava, Czech Republic ${ }^{b}$ Department of Internal Medicine III - Nephrology, Rheumatology and Endocrinology, University Hospital Olomouc and Faculty of Medicine and Dentistry, Palacky University Olomouc

'Stredomoravska nemocnicni, Hospital Sternberk

${ }^{d}$ Department of Clinical Pharmacology, Faculty of Medicine and University Hospital Ostrava

${ }^{e}$ Department of Clinical Pharmacology, Faculty of Medicine and Dentistry, Palacky University Olomouc and University Hospital Olomouc Corresponding author: Nadezda Petejova, e-mail: petejova@seznam.cz

\section{INTRODUCTION}

Acute kidney injury (AKI) is a common complication of critical illness ${ }^{1}$. Between $45-70 \%$ of all AKI is associated with sepsis ${ }^{2}$. Patients with septic AKI have increased risk of death and longer hospitalization ${ }^{3}$.

Critically ill patients in intensive care units are also at high risk of bacterial superinfection caused by nosocomial agents in particular. Both patient status and surroundings contribute to the occurrence of the infection ${ }^{3}$.

Superinfection may be due to type of gram-positive strains of Staphylococcus aureus including methicillin-resistant Staphylococcus aureus (MRSA), and Enterococcus ${ }^{4}$. Treatment with glycopeptid antibiotic agent vancomycin is often required according to the observed sensitivity of bacterial agents 5 . Septic patients with acute kidney injury who are hemodynamically unstable and require high vasopressor support, can be treated with continuous renal replacement therapy (CRRT). Drugs with a molecular weight less than $5000 \mathrm{Da}$, low plasma protein binding, small volume of distribution, and low endogenous clearance are effectively removed by continuous venovenous hemofiltration (CVVH) (ref. $\left.{ }^{6}\right)$. Many drugs used in criti- cally ill patients meet these criteria, complicating dosing regimens in patients receiving CVVH (ref. ${ }^{7}$ ).

The pharmacokinetics of vancomycin can be affected by the filtration dose, physical properties of elimination therapy, type of membrane and also by the properties of the antibiotic agent itself ${ }^{8}$. Dosing and pharmacokinetic data in patients receiving intermittent hemodialysis are not applicable to those receiving CRRT because of substantial differences in procedure, filters and timing. The clearance of vancomycin changes and can be increased using high-flux membranes ${ }^{9}$. An AUC/MIC ratio of $\geq 400$ has been advocated as a target to achieve clinical effectiveness with vancomycin. However, trough vancomycin serum concentration $\mathrm{C}_{\min }>10 \mathrm{mg} / \mathrm{L}$ is more practical method for monitoring vancomycin effectiveness ${ }^{10}$.

The purpose of this study was to assess the influence of CVVH at a filtration rate of $45 \mathrm{~mL} / \mathrm{kg} / \mathrm{h}$ on vancomycin pharmacokinetics in critically ill septic patients with AKI. Using pharmacokinetic modelling, we sought an optimal dosing regimen for maximising target vancomycin exposure. 


\section{PATIENTS AND METHODS}

This was an open, prospective, clinical study carried out at the University hospital Ostrava, Czech Republic. The study protocol was approved by the hospital Ethics Committee. Written informed consent was obtained from patients and two unrelated physicians. Therapeutic monitoring of vancomycin levels is a standard procedure during vancomycin therapy in our hospital.

Seventeen critically ill adult patients (six women) with severe sepsis requiring CRRT in CVVH mode on vancomycin therapy were included. Acute kidney injury was classified according to the RIFLE score: eleven patients belonged to RIFLE F; six patients were in RIFLE I. They were followed up for 2 days. All received vancomycin (Edicin, Sandoz, Lek Pharmaceuticals d.d, Lek, Ljubljana, Slovenia) first dose of $1.0 \mathrm{~g}$ intravenously followed by $1 \mathrm{~g} / 12 \mathrm{~h}$ if not adjusted.

In sixteen patients, vancomycin was introduced on the day of the commencement of CRRT therapy. In one patient, CRRT was initiated in the course of vancomycin treatment. Antibiotic agent was reconstituted with $0.9 \%$ Sodium Chloride $100 \mathrm{~mL}$ solution and administered at an infusion rate of $100 \mathrm{~mL}$ per hour. Blood samples and ultrafiltrates were obtained before vancomycin administration and $0.5,1,6$ and $12 \mathrm{~h}$ after vancomycin administration. Blood samples were collected into $4.9 \mathrm{~mL}$ neutral tubes (Sarstedt-Monovette) and centrifuged. Serum and ultrafiltrate vancomycin concentrations were determined using fluorescence polarisation immunoassay method (AbboTT AxSYM ${ }^{\mathrm{TM}}$; Abbott Laboratories, Diagnostic Division, Abbott Park, IL 60064 USA). Coefficient of variation of the analysis ranged depending on the concentration from $3.36 \%$ to $6.11 \%$ with an average value of $5.04 \%$. Vancomycin dose was adjusted according to vancomycin level simulation using a pharmacokinetic programme MWPharm, version 3.30 (MEDIWARE, Groningen, the Netherlands). A vancomycin trough concentration of $10-15 \mathrm{mg} / \mathrm{L}$ was chosen as a target concentration for vancomycin dosage adjustment. Minimal inhibitory concentration of pathogen was determined by the microdilution broth method.

The following pharmacokinetic parameters were calculated for each patient: total drug clearance $\left(\mathrm{Cl}_{\text {tot }}\right)$, volume of distribution $(\mathrm{Vd})$, elimination half-life $\left(\mathrm{t}_{1 / 2}\right)$ and area under the serum concentration time curve $\left(\mathrm{AUC}_{0-24}\right)$. Pharmacokinetic parameters were calculated using pharmacokinetic programme KINFIT (MWPharm,

Table 1. Demografic data of the study patients.

\begin{tabular}{|c|c|c|c|c|c|c|c|c|c|}
\hline 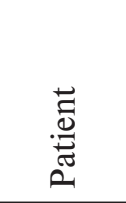 & 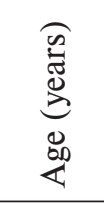 & 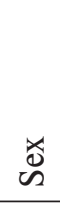 & 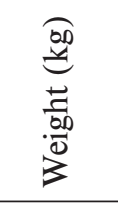 & 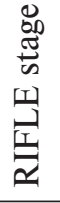 & $\underset{\mathscr{S}}{\mathbb{S}}$ & 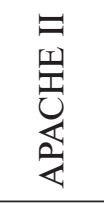 & $\begin{array}{l}\stackrel{\Xi}{\vec{I}} \\
\stackrel{00}{\Xi} \\
6 \\
\exists\end{array}$ & 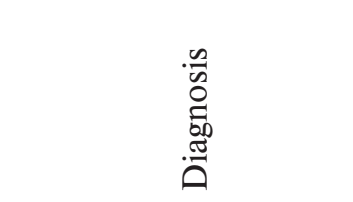 & 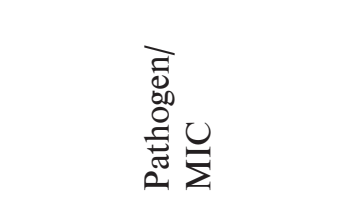 \\
\hline 1 & 68 & $\dagger$ & 113 & $\mathrm{~F}$ & 16 & 34 & 251 & Peritonitis & Staph.species $/ 0.5$ \\
\hline 2 & 73 & $a$ & 73 & $\mathrm{~F}$ & 21 & 31 & $>1000$ & MODS & Staph. species $/ 1.0$ \\
\hline 3 & 44 & $\dagger$ & 90 & $\mathrm{~F}$ & 16 & 31 & 67 & Polytrauma, Sepsis & Ent. faecium $/ 0.5$ \\
\hline 4 & 57 & $\dagger$ & 110 & $\mathrm{~F}$ & 17 & 35 & $>1000$ & CA - bypass,sepsis & Staph. species/1.0 \\
\hline 5 & 71 & $\dagger$ & 90 & I & 21 & 32 & $>1000$ & Pyartros genus 1.dx & Str. pyogenes/0.125 \\
\hline 6 & 28 & $\dagger$ & 80 & $\mathrm{~F}$ & 18 & 26 & $>1000$ & Infectious endocarditis & Staph. aureus/0.5 \\
\hline 7 & 68 & $a$ & 70 & $\mathrm{~F}$ & 21 & 31 & - & Pneumonia & Staph. species/1.0 \\
\hline 8 & 79 & $\dagger$ & 80 & $\mathrm{~F}$ & 14 & 34 & - & Infectious endocarditis & empirically \\
\hline 9 & 59 & $\dagger$ & 100 & $\mathrm{~F}$ & 14 & 28 & 14 & Pneumonia & Staph. species $/ 0.5$ \\
\hline 10 & 45 & $\alpha$ & 58 & I & 15 & 33 & $>1000$ & Peritonitis & Staph. species/- \\
\hline 11 & 54 & $\dagger$ & 100 & I & 17 & 33 & - & Sepsis & Ent. faecalis/1.0 \\
\hline 12 & 50 & $\dagger$ & 110 & I & 15 & 33 & 75 & Mediastinitis & Strep. anginosus $/ 0.25$ \\
\hline 13 & 70 & $\dagger$ & 75 & $\mathrm{~F}$ & 19 & 35 & 62 & Wound infection & Staph. haemolyticus/0.5 \\
\hline 14 & 51 & $a$ & 65 & I & 14 & 28 & 160 & Spondylodiscitis & $M R S A / 0.25$ \\
\hline 15 & 61 & $\dagger$ & 90 & $\mathrm{~F}$ & 16 & 34 & 448 & Pneumonia & MRSA/0.25 \\
\hline 16 & 61 & a & 120 & $\mathrm{~F}$ & 21 & 32 & 59 & Mediastinitis & Ent. faecalis/1.0 \\
\hline 17 & 34 & $\alpha$ & 102 & I & 18 & 22 & 134 & Sepsis & Ent. faecalis $/ 2.0$ \\
\hline Median & 58 & & 90 & & 17 & 32 & 71 & & \\
\hline Range & $28-79$ & & $58-120$ & & $14-21$ & $22-35$ & $14->1000$ & & \\
\hline
\end{tabular}

SOFA - sequential organ failure assessment - score, APACHE - acute physiology and chronic health evaluation - score, IL - interleukin, MIC minimal inhibitory concentration, RIFLE - AKI classification system, F-failure, I-injury, †-men, o-women, MODS - multiple organ dysfunction syndrome, MRSA - methicillin resistant Staphylococcus aureus, CA bypass - coronary artery bypass 
MEDIWARE version 3.60, Groningen, the Netherlands). The selected model was based on a one-compartment model.

CVVH was performed in all patients using a highflux polysulphone membrane: $1.4 \mathrm{~m}^{2}$ AV 600 (5 patients with a body weight less than $80 \mathrm{~kg}$ ) and $1.8 \mathrm{~m}^{2} \mathrm{AV} 1000$ (Fresenius Medical Care, Germany), the blood flow rate $\left(Q_{b}\right)$ was $200 \mathrm{ml} / \mathrm{min}$, ultrafiltrate flow rate $\left(Q_{f}\right)$ was $45 \mathrm{~mL} / \mathrm{kg} / \mathrm{h}$ in pre-postdilution mode (50/50). This procedure was performed using a Multifiltrate machine (Fresenius Medical Care, Germany). The hemofilter was changed every 24 hours. Bicarbonate replacement fluids (Multibic K0-4) were purchased from Fresenius Medical Care, Germany. Low molecular heparin (nadroparine) was used as an anticoagulation, antiXa levels were maintained at 0.3-0.5. CVVH was performed through a doublelumen 14-F catheter inserted into the jugular or femoral vein. CRRT clearance was calculated using the following formula:

$$
\begin{gathered}
\mathrm{Cl}_{\mathrm{CRRT}}=\mathrm{Cl}_{\mathrm{CRRT}}(\text { post })+\mathrm{Cl}_{\mathrm{CRRT}}(\text { pre }) \\
\mathrm{Cl}_{\mathrm{CRRT}} \text { (post) }=\mathrm{Q}_{\mathrm{f}} \times \mathrm{Sc} \quad \mathrm{Cl}_{\mathrm{CRRT}}(\text { pre })=\mathrm{Q}_{\mathrm{f}} \times \mathrm{Sc} \times \mathrm{CF} \\
\mathrm{CF}=\mathrm{Q}_{\mathrm{b}} /\left(\mathrm{Q}_{\mathrm{b}}+\mathrm{Q}_{\text {rep }}\right)\left(\text { ref. }{ }^{5}\right)
\end{gathered}
$$

where $\mathrm{Cl}_{\mathrm{CRRT}}$ (post) $=$ CRRT is the clearance from CRRT using post-filter hemodilution; $\mathrm{Q}_{\mathrm{f}}$ is the ultrafiltration rate; $\mathrm{Cl}_{\text {CRRT }}$ (pre) $=$ CRRT is the clearance from CRRT using pre-filter hemodilution; $\mathrm{Q}_{\mathrm{b}}$ is the blood flow rate; $\mathrm{Q}_{\text {rep }}$ is the pre-dilution replacement rate and $\mathrm{CF}$ the correction factor.

Sieving coefficient was calculated following the formula $\mathrm{C}_{\mathrm{f}} / \mathrm{C}_{\mathrm{pl}}$ where $\mathrm{C}_{\mathrm{f}}$ was vancomycin concentration in ultrafiltrate fluid and $\mathrm{C}_{\mathrm{pl}}$ was vancomycin serum concentration. Data are expressed as median and range. The Spearman correlation was used for correlation coefficients. A p-value of $<0.05$ was considered statistically significant. GraphPad Prism for Windows version 5.0 (GraphPad Prism Software, Inc.) was used to perform the statistical analysis.

\section{RESULTS}

The clinical characteristics of the patients studied are summarized in Table 1. All patients suffered from severe sepsis and were treated with mechanical ventilation. Infections were caused by Gram-positive agents: Staphylococcus species coagulase negat, Methicillinresistant Staphylococcus aureus (MRSA), Staphylococcus haemolyticus, Streptococcus anginosus, Streptococcus pyogenes, Enterococcus faecalis and Enterococcus faecium. Median Acute Physiology and Chronic Health Evaluation (APACHE II) and Sequential Organ Failure Assessment (SOFA) scores at inclusion were 32 (22-35) and 17 (1421). Diuresis was preserved in 11 patients on the first day of the study (range $30-315 \mathrm{~mL} / \mathrm{h}$ ) and in 5 patients on the second study day (range 37-267 mL/h). Diuresis was supported by the diuretic agent furosemide $1.0 \mathrm{~g} / 24 \mathrm{~h}$ (Table $2)$. Median estimated glomerular filtration by MDRD was $0.4(0.1-0.6) \mathrm{mL} / \mathrm{s}$ in both study days.
Table 2. Urine output and ultrafiltration rate in study patients.

\begin{tabular}{ccccc}
\hline \multirow{2}{*}{ Patient } & \multicolumn{2}{c}{$\begin{array}{c}\text { Diuresis } \\
(\mathrm{mL} / \mathrm{h})\end{array}$} & \multicolumn{2}{c}{$\begin{array}{c}\text { Ultrafiltration rate } \\
(\mathrm{mL} / 24 \mathrm{~h})\end{array}$} \\
\cline { 2 - 5 } & Day 1 & Day 2 & Day 1 & Day 2 \\
\hline 1 & 160 & - & 3400 & - \\
2 & anuria & anuria & 1700 & 2300 \\
3 & 30 & 37 & 2800 & 4500 \\
4 & 210 & 133 & 0 & 0 \\
5 & anuria & anuria & 5570 & 6850 \\
6 & 204 & - & 0 & - \\
7 & anuria & anuria & 6000 & 6000 \\
8 & 66 & anuria & 0 & 1700 \\
9 & 36 & anuria & 4670 & 4540 \\
10 & 315 & - & 1900 & - \\
11 & 100 & 267 & 1700 & 2000 \\
12 & 80 & 75 & 1900 & 5100 \\
13 & anuria & anuria & 1400 & 2300 \\
14 & 139 & 113 & 1700 & 4200 \\
15 & anuria & anuria & 3065 & 4740 \\
16 & anuria & anuria & 750 & 3250 \\
17 & 81 & - & 800 & - \\
\hline
\end{tabular}

Vancomycin dosage regimen and vancomycin serum concentrations during both days of the study are depicted in Tables 3 and 4. In three patients, a lower vancomycin dose of $1 \mathrm{~g} / 24 \mathrm{~h}$ was given on the first day, due to acute surgical intervention. Vancomycin serum concentrations after the first dose were below the required target of 10 $\mathrm{mg} / \mathrm{L}$ as early as $6 \mathrm{~h}$ in 10 patients. CRRT therapy was discontinued in 5 patients during the second day and these patients were excluded from further analysis. In the remaining 12 patients, the dose was adjusted in 8 patients. $\mathrm{AUC}_{0-24} / \mathrm{MIC} \geq 400$ ratio was achieved in 10 patients on the first day and in 6 patients on the second day. In 2 patients this ratio could not be determined due to unknown MIC value of pathogen (Tables 5 and 6). The pharmacokinetic parameters are summarized in Tables 5 and 6 . On the first day of treatment, the total clearance of vancomycin (median $0.89 \mathrm{~mL} / \mathrm{min} / \mathrm{kg}$, range 0.31-2.16 $\mathrm{mL} / \mathrm{min} / \mathrm{kg}$ ) approached the average value of total clearance in patients without renal failure $(0.97 \mathrm{~mL} / \mathrm{min} / \mathrm{kg})$ $\left(\right.$ ref. $\left.^{10}\right)$ in 7 of our patients, in 4 patients the total clearance of vancomycin was even higher. On day two the total clearance of vancomycin was equal to the average value of total clearance in only 4 patients. We found a significant correlation between the total vancomycin clearance and the dose/weight $\left(\mathrm{r}_{\mathrm{s}}=0.8289, P=0.0009\right)$ on the second day of the treatment (Fig. 1). No significant relationship between the total clearance of vancomycin and residual renal function was found $(P>0.05)$. 


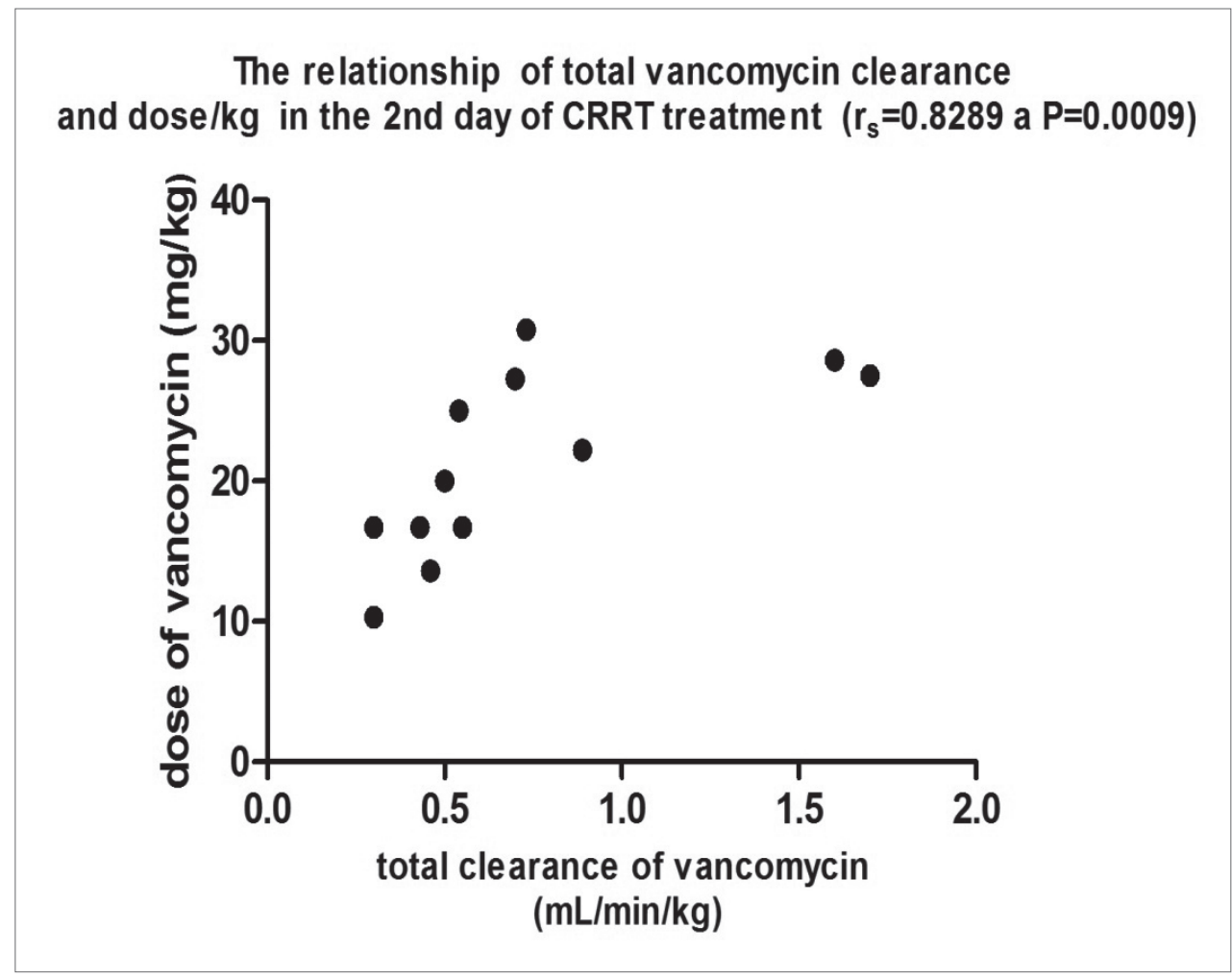

Fig. 1. The relationship between total vancomycin clearance and dose $/ \mathrm{kg}$ on the second day of CRRT treatment $\left(\mathrm{r}_{\mathrm{s}}=0.8289\right.$, $P=0.0009$ ).

Table 3. Vancomycin dose and individual serum concentrations on the first day of study.

\begin{tabular}{|c|c|c|c|c|c|c|c|c|}
\hline \multicolumn{9}{|c|}{ Day 1} \\
\hline 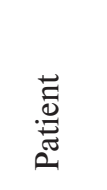 & 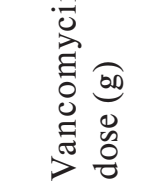 & 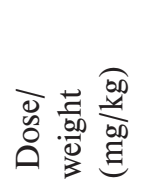 & 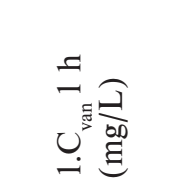 & 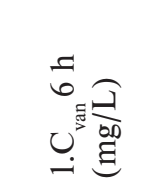 & 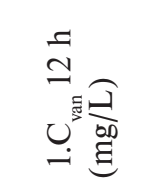 & 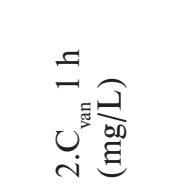 & 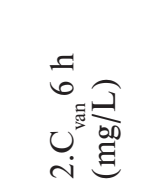 & 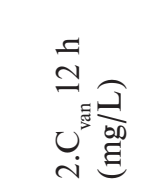 \\
\hline 1 & $1.0 / 12 \mathrm{~h}$ & 17.7 & 15.42 & 7.08 & 3.50 & 14.34 & 9.40 & 5.90 \\
\hline 2 & $1.0 / 12 \mathrm{~h}$ & 27.4 & 32.50 & 21.10 & 18.38 & 27.28 & 19.49 & 15.66 \\
\hline 3 & $1.0 / 12 \mathrm{~h}$ & 22.2 & 30.17 & 20.02 & - & 25.35 & - & 13.41 \\
\hline 4 & $1.0 / 12 \mathrm{~h}$ & 18.2 & 16.58 & 5.37 & 4.00 & 13.70 & 6.83 & - \\
\hline 5 & $1.0 / 12 \mathrm{~h}$ & 22.2 & 12.02 & 6.65 & 5.53 & 18.69 & 11.02 & 7.65 \\
\hline 6 & $1-1.25-1.25$ & 43.8 & 24.99 & 10.96 & - & 29.49 & 13.74 & - \\
\hline 7 & $1.0 / 24 \mathrm{~h}$ & 14.3 & 15.01 & 8.37 & 6.60 & - & - & - \\
\hline 8 & $1.0 / 12 \mathrm{~h}$ & 25.0 & 14.63 & 6.53 & 3.53 & 27.20 & 9.81 & 7.00 \\
\hline 9 & $1.0 / 12 \mathrm{~h}$ & 20.0 & 12.88 & 10.33 & 6.37 & 21.61 & 13.83 & 10.46 \\
\hline 10 & $1.0 / 12 \mathrm{~h}$ & 34.0 & 22.81 & 4.02 & 3.18 & 20.60 & 8.43 & 5.00 \\
\hline 11 & $1.0 / 12 \mathrm{~h}$ & 20.0 & 14.74 & 9.74 & 5.05 & 10.14 & 7.04 & 5.53 \\
\hline 12 & $1.0 / 24 \mathrm{~h}$ & 9.1 & 26.55 & 18.10 & 11.25 & - & - & - \\
\hline 13 & $0.75 / 12 \mathrm{~h}$ & 20.0 & 24.18 & - & 12.78 & 19.34 & - & 12.22 \\
\hline 14 & $1.0 / 12 \mathrm{~h}$ & 30.8 & 31.06 & 14.80 & 11.00 & 20.55 & 18.15 & 11.00 \\
\hline 15 & $1.0 / 12 \mathrm{~h}$ & 22.2 & 10.84 & 7.33 & 5.33 & 16.86 & 11.83 & 9.83 \\
\hline 16 & $1.0 / 24 \mathrm{~h}$ & 8.3 & 26.54 & 8.40 & - & - & - & - \\
\hline 17 & $1.0 / 12 \mathrm{~h}$ & 19.6 & 15.21 & 5.42 & 3.19 & 17.37 & 6.39 & 3.99 \\
\hline$\overline{\text { Median }}$ & & 20.0 & 16.60 & 8.38 & 5.43 & 19.95 & 9.81 & 8.74 \\
\hline Range & & $8.3-43.8$ & $10.84-32.50$ & $4.02-21.10$ & $3.18-18.38$ & $10.14-29.49$ & 6.39-19.49 & $3.99-15.66$ \\
\hline
\end{tabular}

1. $\mathrm{C}_{\mathrm{van}} 1 \mathrm{~h}$ - vancomycin serum concentration 1 hour after $1^{\text {st }}$ dose administration. $1 . \mathrm{C}_{\mathrm{van}} 6 \mathrm{~h}$-vancomycin serum concentration $6 \mathrm{~h}$ after $1^{\text {st }}$ dose administration. $1 . \mathrm{C}_{\text {van }} 12 \mathrm{~h}$ - vancomycin serum concentration $12 \mathrm{~h}$ after $1^{\text {st }}$ dose administration. $2 . \mathrm{C}_{\text {van }} 1 \mathrm{~h}$ - vancomycin serum concentration $1 \mathrm{~h}$ after $2^{\text {nd }}$ dose administration. $2 . \mathrm{C}_{\mathrm{van}} 6 \mathrm{~h}$ - vancomycin serum concentration $6 \mathrm{~h}$ after $2^{\text {nd }}$ dose administration. $2 . \mathrm{C}_{\mathrm{van}} 12 \mathrm{~h}$ - vancomycin serum concentration $12 \mathrm{~h}$ after $2^{\text {nd }}$ dose administration. 
Table 4. Vancomycin dose and individual serum concentrations on the second day of study.

\begin{tabular}{|c|c|c|c|c|c|c|c|c|}
\hline \multicolumn{9}{|c|}{ Day 2} \\
\hline 䒕 & 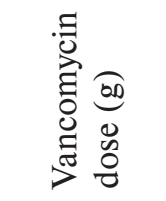 & 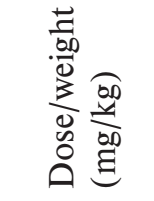 & 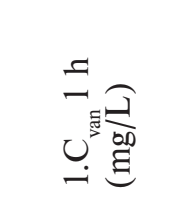 & 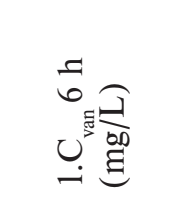 & 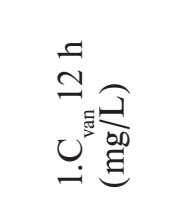 & 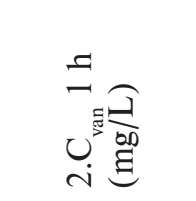 & 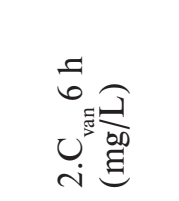 & 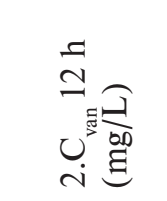 \\
\hline 1 & - & - & - & - & - & - & - & - \\
\hline 2 & $1.0 / 24 \mathrm{~h}$ & 10.3 & 25.68 & 18.82 & 16.63 & - & - & - \\
\hline 3 & $1.0-0.5$ & 16.7 & 21.22 & 22.57 & 15.51 & 18.58 & 18.29 & 12.55 \\
\hline 4 & $1.0 / 8 \mathrm{~h}$ & 27.3 & 17.79 & 10.25 & - & 17.82 & 12.27 & - \\
\hline 5 & $0.75 / 12 \mathrm{~h}$ & 16.7 & 21.38 & 13.60 & 10.75 & 22.79 & 13.39 & 10.31 \\
\hline 6 & - & - & - & - & - & - & - & - \\
\hline 7 & $1.0 / 12 \mathrm{~h}$ & 28.6 & 14.94 & 7.76 & 6.43 & 21.30 & 12.56 & 9.52 \\
\hline 8 & $1.0 / 12 \mathrm{~h}$ & 25.0 & 22.12 & 13.91 & 10.69 & 22.62 & 16.01 & 13.79 \\
\hline 9 & $1.0 / 12 \mathrm{~h}$ & 20.0 & 22.39 & 13.00 & 10.00 & 27.01 & 18.11 & 12.09 \\
\hline 10 & - & - & - & - & - & - & - & - \\
\hline 11 & $1.25-1.5$ & 27.5 & 24.36 & 10.21 & 6.46 & 35.52 & 8.70 & 6.82 \\
\hline 12 & $0.75 / 12 \mathrm{~h}$ & 13.6 & 15.22 & 8.31 & 8.22 & 22.68 & 11.05 & 8.28 \\
\hline 13 & - & - & - & - & - & - & - & - \\
\hline 14 & $1.0 / 12 \mathrm{~h}$ & 30.8 & 36.35 & 19.18 & 11.00 & 25.74 & 16.78 & 10.00 \\
\hline 15 & $1.0 / 12 \mathrm{~h}$ & 22.2 & 20.55 & 10.56 & 8.56 & 21.54 & - & 13.00 \\
\hline 16 & $1.0 / 12 \mathrm{~h}$ & 16.7 & 13.32 & 8.22 & 6.40 & 17.20 & 14.52 & 10.00 \\
\hline 17 & - & - & - & - & - & - & - & - \\
\hline Median & & 21.1 & 21.30 & 11.78 & 10.00 & 22.62 & 13.96 & 10.16 \\
\hline Range & & $10.3-30.8$ & $13.32-36.35$ & $7.76-22.57$ & $6.40-16.63$ & $17.20-35.52$ & $8.70-18.29$ & $6.82-13.79$ \\
\hline
\end{tabular}

1. $\mathrm{C}_{\mathrm{van}} 1 \mathrm{~h}$ - vancomycin serum concentration $1 \mathrm{~h}$ after $1^{\text {st }}$ dose administration. $1 . \mathrm{C}_{\mathrm{van}} 6 \mathrm{~h}$ - vancomycin serum concentration $6 \mathrm{~h}$ after $1^{\text {st }}$ dose administration. $1 . \mathrm{C}_{\text {van }} 12 \mathrm{~h}$ - vancomycin serum concentration $12 \mathrm{~h}$ after $1^{\text {st }}$ dose administration. $2 . \mathrm{C}_{\text {van }} 1 \mathrm{~h}$ - vancomycin serum concentration 1 $\mathrm{h}$ after $2^{\text {nd }}$ dose administration. $2 . \mathrm{C}_{\text {van }} 6 \mathrm{~h}$ - vancomycin serum concentration $6 \mathrm{~h}$ after $2^{\text {nd }}$ dose administration. $2 . \mathrm{C}_{\mathrm{van}} 12 \mathrm{~h}-$ vancomycin serum concentration $12 \mathrm{~h}$ after $2^{\text {nd }}$ dose administration.

\section{DISCUSSION}

We studied the pharmacokinetics of vancomycin in critically ill septic patients with acute kidney injury treated with CRRT in order to establish practical recommendations for a vancomycin dosage regimen. $\mathrm{CVVH}$ at a filtration rate of $45 \mathrm{~mL} / \mathrm{kg} / \mathrm{h}$ led to high and rapid extracorporeal removal of vancomycin in critically ill patients. However, due to rapid change in patient clinical status it was impossible to predict a fixed dosage regimen.

Extracorporeal elimination is clinically significant if it achieves $25-30 \%$ of total drug clearance ${ }^{5}$. Deldot et al. studied vancomycin clearance in 10 critically ill patients treated with continuous venovenous hemodiafiltration at a dialysis dose of $1000 \mathrm{~mL} / \mathrm{h}$ and a filtration dose of 2000 $\mathrm{mL} / \mathrm{h}$. The total vancomycin clearance was $2.5 \pm 0.7 \mathrm{~L} / \mathrm{h}$ and CVVHDF clearance was $76 \pm 16.5 \%$ of a total drug clearance ${ }^{11}$. Uchino et al. observed vancomycin clearance in 7 septic patients with multiple organ failure and AKI treated with high-volume venovenous hemofiltration at a filtration rate of $6 \mathrm{~L} / \mathrm{h}$ with varying pre and postdilution flow rate ${ }^{12}$. They found that total vancomycin clearance increased when predilution flow rate was reduced from $4 \mathrm{~L}$ to $2 \mathrm{~L}$ in the range of 53.9 to $67.2 \mathrm{~mL} / \mathrm{min}$. Shah et al. describes a 14-year-old critically ill patient with AKI treated with CVVH at a filtration rate of $1800 \mathrm{~mL} / \mathrm{h}, \mathrm{CVVH}$ clearance was $26 \pm 0.8 \mathrm{~mL} / \mathrm{min}^{13}$. In our study CRRT clearance at a filtration rate of $45 \mathrm{~mL} / \mathrm{kg} / \mathrm{h}$ accounted for approximately $50-60 \%$ of the total clearance of vancomycin found in a population with normal renal function, therefore it contributes significantly to the elimination of vancomycin in septic patients with AKI. Interestingly in three anuric patients, the total clearance of vancomycin was higher than the CRRT clearance and approached the plasma clearance of vancomycin in populations without renal impairment $(0.97 \mathrm{~mL} / \mathrm{min} / \mathrm{kg})\left(\right.$ ref. $\left.{ }^{10,14,15}\right)$. In four patients, the total clearance of vancomycin was even higher than in populations without renal disease (1.24 to 2.16 $\mathrm{mL} / \mathrm{min} / \mathrm{kg}$ ).

The total drug clearance is the sum of non-CRRT and CRRT clearance, which means that different factors are involved in the excretion of antibiotics. One of the important factors is residual renal function. Patients with residual diuresis may require an increased dose of vancomycin to maintain desired serum levels. In our study, however, we found no significant correlation between the total clearance of vancomycin and residual diuresis. In patients with oligoanuric AKI a substantial non-renal 
Table 5. Pharmacokinetic/pharmacodynamic parameters of vancomycin during CRRT ( $45 \mathrm{~mL} / \mathrm{kg} / \mathrm{h})$ treatment on the first day of study.

\begin{tabular}{|c|c|c|c|c|c|c|c|}
\hline \multicolumn{8}{|c|}{ Day 1} \\
\hline Patient & $\begin{array}{c}\mathrm{Cl}_{\mathrm{tot}} \\
(\mathrm{mL} / \mathrm{min} / \mathrm{kg})\end{array}$ & $\begin{array}{c}\mathrm{Vd} \\
(\mathrm{L} / \mathrm{kg})\end{array}$ & $\begin{array}{l}\mathrm{t}_{1 / 2} \\
(\mathrm{~h})\end{array}$ & $\mathrm{AUC}_{0-24}$ & $\mathrm{AUC}_{0-24} / \mathrm{MIC}$ & $\underset{(\mathrm{mL} / \mathrm{min} / \mathrm{kg})}{\mathrm{Cl}_{\mathrm{CRRT}}}$ & $\mathrm{Sc}$ \\
\hline 1 & 0.89 & 0.43 & 5.80 & 245.9 & 491.8 & 0.5 & 0.64 \\
\hline 2 & 0.45 & 0.38 & 9.88 & 559.7 & 559.7 & 0.5 & 0.72 \\
\hline 3 & 0.38 & 0.34 & 11.06 & 515.0 & 1030.0 & 0.4 & 0.65 \\
\hline 4 & 1.24 & 0.46 & 4.32 & 184.8 & 184.8 & 0.5 & 0.68 \\
\hline 5 & 0.97 & 0.71 & 8.34 & 233.8 & 1870.1 & 0.6 & 0.78 \\
\hline 6 & 1.04 & 0.49 & 5.49 & 396.1 & 792.2 & 0.6 & 0.73 \\
\hline 7 & 1.07 & 1.06 & 11.48 & 170.4 & 170.4 & 0.6 & 0.73 \\
\hline 8 & 1.32 & 0.57 & 4.99 & 256.8 & - & 0.6 & 0.80 \\
\hline 9 & 0.68 & 0.56 & 9.83 & 280.2 & 560.4 & 0.6 & 0.73 \\
\hline 10 & 2.16 & 0.77 & 4.14 & 246.8 & - & 0.8 & 0.77 \\
\hline 11 & 0.96 & 0.74 & 8.95 & 205.7 & 205.7 & 0.6 & 0.73 \\
\hline 12 & 0.31 & 0.35 & 13.22 & 329.9 & 1319.6 & 0.6 & 0.73 \\
\hline 13 & 0.49 & 0.51 & 11.68 & 375.0 & 750.0 & 0.5 & 0.73 \\
\hline 14 & 0.73 & 0.55 & 8.88 & 410.9 & 1640.0 & 0.6 & 0.73 \\
\hline 15 & 0.86 & 0.69 & 9.31 & 142.0 & 568.0 & 0.6 & 0.78 \\
\hline 16 & 0.59 & 0.32 & 6.33 & 192.4 & 192.4 & 0.6 & 0.77 \\
\hline 17 & 1.38 & 0.61 & 5.25 & 181.9 & 90.9 & 0.6 & 0.73 \\
\hline Median & 0.89 & 0.55 & 8.88 & & & 0.6 & 0.73 \\
\hline Range & $0.31-2.16$ & $0.32-1.06$ & $4.14-13.22$ & & & $0.4-0.8$ & $0.64-0.80$ \\
\hline
\end{tabular}

$\mathrm{Cl}_{\text {tot }}$ - total drug clearance. $\mathrm{Vd}$ - volume of distribution. $\mathrm{t}_{1 / 2}$ - elimination half-life. $\mathrm{Cl}_{\mathrm{CRRT}}-\mathrm{CRRT}$ clearance. Sc - sieving coefficient. AUC $\mathrm{A}_{024} /$ MIC - area under the serum concentration time curve $0-24 \mathrm{~h}$ to minimal inhibitory concentration ratio

Table 6. Pharmacokinetic/pharmacodynamic parameters of vancomycin during CRRT ( $45 \mathrm{~mL} / \mathrm{kg} / \mathrm{h})$ treatment on the second day of study.

\begin{tabular}{|c|c|c|c|c|c|c|c|}
\hline \multicolumn{8}{|c|}{ Day 2} \\
\hline Patient & $\begin{array}{c}\mathrm{Cl}_{\text {tot }} \\
(\mathrm{mL} / \mathrm{min} / \mathrm{kg})\end{array}$ & $\begin{array}{c}\mathrm{Vd} \\
(\mathrm{L} / \mathrm{kg})\end{array}$ & $\begin{array}{l}t_{1 / 2} \\
(h)\end{array}$ & $\mathrm{AUC}_{0-24}$ & $\mathrm{AUC}_{0-24} / \mathrm{MIC}$ & $\begin{array}{c}\mathrm{Cl}_{\mathrm{CRRT}} \\
(\mathrm{mL} / \mathrm{min} / \mathrm{kg})\end{array}$ & Sc \\
\hline 1 & - & - & - & - & - & - & - \\
\hline 2 & 0.30 & 0.34 & 12.85 & 351.2 & 351.2 & 0.6 & 0.75 \\
\hline 3 & 0.30 & 0.37 & 14.15 & 342.7 & 685.4 & 0.5 & 0.69 \\
\hline 4 & 0.70 & 0.34 & 5.61 & 366.2 & 366.2 & 0.5 & 0.63 \\
\hline 5 & 0.43 & 0.35 & 9.41 & 360.0 & 2880.0 & 0.6 & 0.74 \\
\hline 6 & - & - & - & - & - & - & - \\
\hline 7 & 1.06 & 0.77 & 8.41 & 278.1 & 278.1 & 0.5 & 0.67 \\
\hline 8 & 0.54 & 0.53 & 11.77 & 384.5 & - & 0.5 & 0.63 \\
\hline 9 & 0.50 & 0.38 & 8.67 & 395.1 & 790.2 & 0.6 & 0.76 \\
\hline 10 & - & - & - & - & - & - & - \\
\hline 11 & 1.07 & 0.43 & 4.71 & 343.6 & 343.6 & 0.5 & 0.68 \\
\hline 12 & 0.46 & 0.36 & 9.06 & 287.3 & 1149.2 & 0.5 & 0.65 \\
\hline 13 & - & - & - & - & - & - & - \\
\hline 14 & 0.73 & 0.43 & 6.81 & 485.5 & 1942.0 & 0.5 & 0.63 \\
\hline 15 & 0.89 & 0.78 & 10.85 & 230.3 & 921.2 & 0.6 & 0.73 \\
\hline 16 & 0.55 & 0.54 & 11.66 & 270.5 & 270.5 & 0.5 & 0.63 \\
\hline 17 & - & - & - & - & - & - & - \\
\hline Median & 0.55 & 0.41 & 9.24 & & & 0.5 & 0.68 \\
\hline Range & $0.30-1.07$ & $0.34-0.78$ & $4.71-14.15$ & & & $0.5-0.6$ & $0.63-0.76$ \\
\hline
\end{tabular}

$\mathrm{Cl}_{\text {tot }}$ - total drug clearance. $\mathrm{Vd}$ - volume of distribution. $\mathrm{t}_{1 / 2}$ - elimination half-life. $\mathrm{Cl}_{\mathrm{CRRT}}-\mathrm{CRRT}$ clearance. Sc - sieving coefficient. AUC $\mathrm{A}_{0-24} /$ MIC - area under the serum concentration time curve $0-24 \mathrm{~h}$ to minimal inhibitory concentration ratio 
clearance initially has been observed ${ }^{16}$. The proportion of non-renal clearance can vary between 3.8 to $23.3 \mathrm{~mL} / \mathrm{min}$ in patients with AKI compared with only $4-6 \mathrm{~mL} / \mathrm{min}$ in patients with chronic renal failure ${ }^{17}$. Further vancomycin adsorption to hemofilter has also been described ${ }^{18}$. These factors could explain the discrepancy observed between total vancomycin clearance and CRRT clearance in our anuric patients and lack of correlation between the total clearance and diuresis. In four cases, we found paradoxically lower total clearance of vancomycin than CRRT clearance. The only explanation for this discrepancy is that these patients were disconnected from continuous elimination for several hours due to urgent intervention or due to repeated precipitation which led to the reduction in the total vancomycin clearance.

Sepsis can lead to endothelial damage with increased capillary permeability and can change the volume of distribution. Changes in the volume of distribution are important especially for hydrophilic substances. Increased volume of distribution has been observed for example in septic patients treated with aminoglycosides requiring an increase of daily dose to achieve therapeutic concentrations ${ }^{19}$. However, it seems that changes in fluid balance have less impact on the volume of distribution with vancomycin than with aminoglycosides. In our patients, we observed approximately the same volume of distribution as described in healthy volunteers ${ }^{17}$. Choi et al. describes volume of distribution of $0.55 \pm 0.12 \mathrm{~L} / \mathrm{kg}$ in septic patients treated with CVVH which corresponds to our findings $^{20}$. Elimination half-life of vancomycin was longer in our patients (ranging from $4.14 \mathrm{~h}$ to $14.15 \mathrm{~h}$ ) than in nonseptic patients without renal impairment (approximately 4-6 h) (ref. $\left.{ }^{10,14,15}\right)$.

Trotman et al. recommends in critically ill patients an initial dose of vancomycin $15-20 \mathrm{mg} / \mathrm{kg}$ and a maintenance dose of $500 \mathrm{mg}$ to $1500 \mathrm{mg}$ every $24 \mathrm{~h}$ to $48 \mathrm{~h}$ in CVVHD and a dose of 1000-1500 mg every $24 \mathrm{~h}$ in CVVHDF to achieve trough concentration in the range of $10-15 \mathrm{mg} / \mathrm{L}$ (ref. ${ }^{19}$ ). Veltri et al. recommended an initial dose of $10-15 \mathrm{mg} / \mathrm{kg}$ parenterally followed by vancomycin concentrations monitoring in septic patients treated with CRRT in all modes ${ }^{21}$. The initial median daily dose of vancomycin in our group of patients was $20.0 \mathrm{mg} / \mathrm{kg}$ ( 8.3 to 43.8 ) with a loading dose of $1.0 \mathrm{~g}$, maintenance dose was based on vancomycin serum concentrations. Total clearance of patients varied in a wide range and thus reflected the need for different weight-based doses of vancomycin. However, giving a standard initial dose of 1 $\mathrm{g}$ intravenously has lead to a drop of trough levels below $10 \mathrm{mg} / \mathrm{L}$ as early as $6 \mathrm{~h}$ after first drug administration in 10 of our patients. A weight-based initial vancomycin dose rather than fixed dose is proposed to rapidly achieve optimal therapeutic vancomycin concentrations. A loading dose of $25-30 \mathrm{mg} / \mathrm{kg}$ has been recommended in an effort of minimizing subtherapeutic exposures within the first $24 \mathrm{~h}\left(\right.$ ref. $\left.^{10}\right)$. However caution should be taken when applying this recommendation to the population with renal impairment. Septic patients are usually in a severe catabolic status and often need a different dose of RRT.
They might often require changes in ultrafiltration flow rates leading to different elimination of antibiotics and thus making drug dosage more difficult. Boumann et al. observed a significant discrepancy between predicted and observed vancomycin removal with the need for dose adjustments and more frequent monitoring of serum levels in 45 oligoanuric patients treated with CVVH $\left(\right.$ ref. $^{22}$ ). Due to rapid changes in patient clinical status and CRRT conditions, it may be therefore impossible to derive a fixed dosage regimen in critically ill septic patients and maintenance doses should be based on vancomycin concentration monitoring.

An AUC/MIC ratio $\geq 400$ has been advocated as a target to achieve clinical effectiveness with vancomycin therapy ${ }^{10}$. However, because it can be difficult in the clinical setting to obtain multiple serum vancomycin concentrations to determine AUC and then calculate AUC/MIC, trough serum concentration monitoring, which can be used as a surrogate marker for AUC, is recommended as the most accurate and most practical method for vancomycin monitoring. Trough vancomycin serum concentrations maintained above $10 \mathrm{mg} / \mathrm{L}$ are recommended ${ }^{10}$. The desired $\mathrm{AUC}_{0-24} / \mathrm{MIC} \geq 400$ was achieved in $67 \%$ of patients on the first day and $55 \%$ on the second day of treatment. The desired AUC/MIC ratio was achieved almost only in patients with vancomycin MIC $<1.0 \mathrm{mg} / \mathrm{L}$. Recent study recommends a higher trough vancomycin concentration of between $15-20 \mathrm{mg} / \mathrm{L}$ especially in the treatment of complicated infections (e.g. ventilatory associated pneumonia) and for a pathogen with an MIC of $1 \mathrm{mg} / \mathrm{L}$ in order to attain target vancomycin exposure ${ }^{10,23}$. Higher trough vancomycin concentrations may also increase the potential for nephrotoxicity but the extent of this risk is yet to be determined. Vancomycin-induced nephrotoxicity is related to drug plasma concentrations ${ }^{24}$. Nephrotoxicity is a concern for those hemodialysis patients who have some residual renal function and mainly for those patients with AKI. A target AUC/MIC $\geq 400$ is not achievable with conventional dosing methods if the pathogen vancomycin $\mathrm{MIC}$ is $\geq 2 \mathrm{mg} / \mathrm{L}$, achievement of this ratio would lead to undesirable vancomycin toxicity. To further improve treatment options, use of predictive pharmacokinetic simulation for predicting plasma levels of vancomycin is recommended ${ }^{25}$.

\section{CONCLUSION}

Therapeutic monitoring of vancomycin levels in critically ill septic patients treated with renal replacement therapy is a valuable tool in drug dosage adjustment. Due to the unstable patient's clinical status and possible changing conditions of RRT daily monitoring of vancomycin serum levels is necessary at least for the first days after antibiotic introduction. Achievement of adequate vancomycin concentration on the first day of treatment of septic patients is of high clinical importance. We recommend performance of blood sample as early as $6 \mathrm{~h}$ after first vancomycin dose in case of a need of early dose adjustment. 


\section{ACKNOWLEDGEMENTS}

The authors thank all of the doctors and nurses of all the intensive care units that contributed to this study. This project was supported by grant IGA MZCR NS 103 09-3/2009.

\section{CONFLICT OF INTEREST STATEMENT}

The authors stated that there are no conflicts of interest regarding the publication of this article.

\section{REFERENCES}

1. Uchino S, Kellum JA, Bellomo R, Doig GS, Morimatsu H, Morgera $S$ Schetz M, Tan I, Bouman C, Macedo E, Gibney N, Tolwani A, Ronco C; Beginning and Ending Supportive Therapy for the Kidney (BEST Kidney) Investigators.Acute renal failure in critically ill patients: a multinational, multicenter study. JAMA 2005;294:813-8.

2. Bagshaw SM, Laupland KB, Doig CJ, Mortis G, Fick GH, Mucensk $M$, Godinez-Luna T, Svenson LW, Rosenal T.Prognosis for long-term survival and renal recovery in critically ill patients with severe acute renal failure: a population-based study. Crit Care 2005;9:R700-9.

3. Bagshaw SM, Uchino S, Bellomo R, Morimatsu H, Morgera S, Schetz M, Tan I, Bouman C, Macedo E, Gibney N, Tolwani A, Oudemans-van Straaten HM, Ronco C, Kellum JA; Beginning and Ending Supportive Therapy for the Kidney (BEST Kidney) Investigators.Septic acute kidney injury in critically ill patients: clinical characteristics and outcomes. Clin J Am Soc Nephrol 2007;2:431-9.

4. Grüneberg RN, Wilson AP.Anti-infective treatment in intensive care: the role of glycopeptides. Intensive Care Med 1994;20 Suppl 4:S1722.

5. Choi G, Gomersall CD, Tian Q, Joynt GM, Li AM, Lipman J. Principles of antibacterial dosing in continuous renal replacement therapy. Blood Purif 2010;30:195-212.

6. Golper TA, Wedel SK, Kaplan AA, Saad AM, Donta ST, Paganini EP. Drug removal during continuous arteriovenous hemofiltration: theory and clinical observations. Int J Artif Organs 1985;8:307-12.

7. Boereboom FT, Ververs FF, Blankestijn PJ, Savelkoul TJ, van Dijk A.Vancomycin clearance during continuous venovenous haemofiltration in critically ill patients. Intensive Care Med 1999;25:1100-4.

8. Schetz M, Ferdinande P, Van den Berghe G, Verwaest C, Lauwers $P$. Pharmacokinetics of continuous renal replacement therapy. Intensive Care Med 1995;21:612-20.

9. Petejova N, Martinek A, Zahalkova J, Duricova J, Brozmanova H, Urbanek K, Grundmann M, Kacirova I. Vancomycin removal during low-flux and high-flux extended daily hemodialysis in critically ill septic patiens. Biomed Pap Med 2012;156:XX. DOI 10.5507/ bp.2012.002, available online: January 30, 2012.
10. Rybak MJ, Lomaestro BM, Rotschafer JC, Moellering R Jr, Craig W, Billeter M, Dalovisio JR, Levine DP. Therapeutic monitoring of vancomycin in adults summary of consensus recommendations from the American Society of Health-System Pharmacists, the Infectious Diseases Society of America, and the Society of Infectious Diseases Pharmacists. Am J Health-Syst Pharm 2009;66:82-98.

11. DelDot ME, Lipman J, Tett SE.Vancomycin pharmacokinetics in critically ill patients receiving continuous venovenous haemodiafiltration. Br J Clin Pharmacol 2004;58:259-68.

12. Uchino S, Cole L, Morimatsu H, Goldsmith D, Bellomo R.Clearance of vancomycin during high-volume haemofiltration: impact of predilution. Intensive Care Med. 2002;28:1664-7.

13. Shah M, Quigley R. Rapid removal of vancomycin by continuous veno-venous hemofiltration. Pediatr Nephrol 2000;14:912-5.

14. http://www.sukl.cz/download/spc/SPC108984.doc (vancomycin product information).

15. http://www.sukl.cz/download/spc/SPC59482.doc (vancomycin product information).

16. Macias WL, Mueller BA, Scarim SK.Vancomycin pharmacokinetics in acute renal failure: preservation of nonrenal clearance.Clin Pharmacol Ther 1991;50:688-94.

17. Burton ME, Shaw LM, Scheritag JJ, Evans WE. Applied Pharmacokinetics \& Pharmacodynamics Principles of Therapeutic Drug Monitoring. 4.vyd. Philadelphia PA: Lippincote Williams \& Wilkins 2006:285-353.

18. Reetze-Bonorden P, Böhler J, Keller E. Drug dosage in patients during continuous renal replacement therapy. Pharmacokinetic and therapeutic considerations. Clin Pharmacokinet 1993;24:362-79.

19. Trotman RL, Williamson JC, Shoemaker DM, Salzer WL. Antibiotic dosing in critically ill adult patients receiving continuous renal replacement therapy. Clin Infect Dis 2005;41:1159-66.

20. Choi G, Gomersall ChD, Tian Q, Joynt GM, Freebairn R, Lipman J. Principles of antibacterial dosing in continuous renal replacement therapy. Critical Care Medicine 2009;7:2268-82.

21. Veltri MA, Neu AM, Fivush BA, Parekh RS, Furth SL. Drug dosing during intermittent hemodialysis and continuous renal replacement therapy: special considerations in pediatric patients. Paediatr Drugs 2004:6:45-65.

22. Bouman CS, van Kan HJ, Koopmans RP, Korevaar JC, Schultz MJ, Vroom MB. Discrepancies between observed and predicted continuous venovenous hemofiltration removal of antimicrobial agents in critically ill patients and the effects on dosing. Intensive Care Med 2006:32:2013-19.

23. Brochard L, Abroug F, Brenner M, Broccard AF, Danner RL, Ferrer M, Laghi F, Magder S, Papazian L, Pelosi P, Polderman KH; ATS/ERS/ ESICM/SCCM/SRLF Ad Hoc Committee on Acute Renal Failure. An Official ATS/ERS /ESICM /SCCM /SRLF Statement: Prevention and Management of Acute Renal Failure in the ICU Patient: an international consensus conference in intensive care medicine. Am J Respir Crit Care Med 2010;181:1128-55.

24. Rybak MJ. The Pharmacokinetic and Pharmacodynamic Properties of Vancomycin. Clin Inf Dis 2006;42:S35-9.

25. Zahálková J, Strojil J, Petejová N, Urbánek K, Grundmann M, Kacírová I. Dávkování vankomycinu při kontinuální náhradě funkce ledvin. Klin Farmakol Farm 2011;25:116-21. 